\title{
Editorial
}

\section{How to Brush Your Way into the Bile Duct}

\author{
Pedro Bastos $^{\mathrm{a}}$ Inês Pita ${ }^{\mathrm{b}} \quad$ Aníbal Ferreira $^{\mathrm{c}}$ \\ a Serviço de Gastroenterologia, Instituto Português de Oncologia do Porto, Porto, Portugal; \\ bServiço de Gastroenterologia, Instituto Portugues de Oncologia Francisco Gentil, Porto, Portugal; \\ 'Departamento de Gastrenterologia, Hospital de Braga, Braga, Portugal
}

Keywords

ERCP · Brush cytology · Biliary strictures

\section{Como realizar eficazmente citologia biliar \\ Palavras Chave \\ CPRE · Citologia por escovado - Estenose biliar}

The diagnosis of indeterminate biliary strictures remains a major challenge in the field of pancreatobiliary endoscopy. In an era of personalized medicine, the goal is to obtain a cytohistological diagnosis before proceeding to therapeutic actions. This objective is particularly difficult to achieve in the biliary tree due to several factors, which include the complex access route, the low cellularity and desmoplastic nature of some cholangiocarcinomas, and the systemic nature of some diseases that affect the biliary tree, such as autoimmune cholangitis and some infections. One should always keep in mind that approximately $30 \%$ of biliary strictures have a benign etiology and that in up to a quarter of resected cases, malignancy is not confirmed in the ex vivo examination.

\section{KARGER}

E-Mail karger@karger.com www.karger.com/pjg
(C) 2018 Sociedade Portuguesa de Gastrenterologia Published by S. Karger AG, Basel

Karger

Open access

This article is licensed under the Creative Commons AttributionNonCommercial-NoDerivatives 4.0 International License (CC BYNC-ND) (http://www.karger.com/Services/OpenAccessLicense). Usage and distribution for commercial purposes as well as any distribution of modified material requires written permission.
ERCP with brush cytology is considered a cornerstone exam in such cases and is probably the most frequently used endoscopic method. Despite its wide application, ERCP with brush cytology is hampered by a modest sensitivity and by the conspicuous adverse event rate associated to ERCP [1]. In order to improve the accuracy rate, several approaches have been proposed. These include doing additional procedures during ERCP such as fluoroscopic guided biopsies, fluorescent in situ hybridization (FISH), and cholangioscopy, whether using the single operator or direct peroral modality. A different approach based on endoscopic ultrasound is also possible, with the sensitivity of fine-needle biopsy of biliary lesions reaching $80 \%$ in a recent meta-analysis [2]. All these methods have pros and cons, but in general are not universally available and require extensive expertise.

In this issue of GE - Portuguese Journal of Gastroenterology, Costa et al. [3] publish their experience with biliary brush cytology focusing on the method used to collect the cellular sample and on age as a factor to obtain a diagnosis of malignancy. One of the authors' main findings is a trend for improved sensitivity when different methods were combined. In fact, increasing the number of strategies for tissue acquisition (doing standard smears; cutting 
the tip of the brush and emerging it in a fixative solution; flushing the brush sheath) theoretically improves the possibility of a definitive diagnosis as this could increase the cellularity of the specimen. The results of brush cytology in this study are in line with other published series, with a sensitivity of $40 \%$ in the standard smear group, increasing to $60 \%$ when liquid fixation of the brush was added. The emphasis should remain in the need to combine different strategies and, when indicated, repeat brush cytology since this usually increases the diagnostic yield [4].

Several predictors of a positive diagnosis were evaluated and only younger age presented as a factor related to a positive diagnosis. This finding is difficult to understand and contradicts previous reports. Nonetheless, it can be speculated as a derivative of the biology of the lesions in this age group. The previous study that showed a positive relation between older age and positive diagnosis had a higher number of patients and found other variables which also related with a positive diagnosis [5]. However, no practical conclusion can be taken from this and the gradual evolution of tissue acquisition methods will hopefully evolve to a high diagnostic yield in all age groups.

Proper tissue sampling in pancreatobiliary diseases is a complex subject and no perfect method exists. Each center should have an audited diagnosis algorithm. Standard brush cytology, despite its pitfalls, is widely available and endoscopists should be aware of possible improvements in the technique. Repeating the procedure and diversifying means to collect the sample can increase the diagnostic yield and be enough in the majority of the cases. Direct endoscopic evaluation and biopsy through cholangioscopy will probably be the tiebreaker in indefinite or more difficult cases.

\section{Disclosure Statement}

The authors have no conflicts of interest to declare.
References
1 Navaneethan U, Njei B, Lourdusamy V, Konjeti R, Vargo JJ, Parsi MA: Comparative effectiveness of biliary brush cytology and intraductal biopsy for detection of malignant biliary strictures: a systematic review and meta-analysis. Gastrointest Endosc 2015;81: 168-176.

-2 Sadeghi A, Mohamadnejad M, Islami F, Keshtkar A, Biglari M, Malekzadeh R, Eloubeidi MA: Diagnostic yield of EUS-guided FNA for malignant biliary stricture: a systematic review and meta-analysis. Gastrointest Endosc 2016;83:290-298.e1.
3 Costa M, Canena J, Mascarenhas-Lemos L, Loureiro R, Silva M, Carvalho D, Capela T, Russo P, Ramos G, Mateus-Dias A, FerrazOliveira M, Veiga PM, Coimbra J: Outcomes of different methods for analysis of biliary brush cytology and of factors associated with positive diagnosis in an age-dependent retrospective review. GE Port J Gastroenterol 2018, DOI: $10.1159 / 000487153$.

4 Korc P, Sherman S: ERCP tissue sampling. Gastrointest Endosc 2016;84:557-571.

5 Mahmoudi N, Enns R, Amar J, AlAli J, Lam E, Telford J: Biliary brush cytology: factors associated with positive yields on biliary brush cytology. World J Gastroenterol 2008; 14: 569-573. 